\title{
THE EUROPEAN MONITORING CENTRE FOR DRUGS AND DRUG ADDICTION - SELECTED SYSTEM-WIDE ISSUES AND ACTIVITIES
}

\author{
Katarzyna Woch*
}

\begin{abstract}
The issue of drugs is an important problem for the European citizens and it poses a serious threat to safety and health of the European society. This is mainly due to the fact that one of the basic features characterizing the problem of drugs is its changeable and dynamic nature. Furthermore, the drug-related phenomena have no borders, they exist everywhere where people live and affect all social classes.

The European Union is one of the international organizations which, both by its own activities and the efforts of the member states, attempts to prevent and fight the adverse effects associated with drug abuse. The implementation of such a goal is possible thanks to the activities of the agency responsible for the holistic study of the problem of drugs and drug addiction and for popularization of the obtained information among the EU institutions, Member States and other organizations.

The purpose of the article is to present the activities of the European Monitoring Centre for Drugs and Drug Addiction, whose role is to provide factual, objective, reliable and comparable information of the European standard on drugs and drug addiction as well as their effects both on the European Union itself and the member states.
\end{abstract}

Key words: EU agency, drugs, Reitox, European Union

\section{INTRODUCTION}

Cooperation of the European states with respect to drugs was for the first time initiated outside the European Communities. A proposal for

M.A., an assistant lecturer at the European Union Law Department of John Paul II Catholic University of Lublin, katarzyna.woch@kul.pl. 
cooperation in the field of the growing problem of drugs, outside the framework of the Treaty of Rome, was made in 1971 by the president of France G. Pompidou. Initially, the "Pompidou Group" was an informal inter-governmental forum within which seven states - the Netherlands, Belgium, Luxemburg, Germany, France, Italy and Great Britain - shared their experience in combating drug abuse and drug trafficking. Its activity was formalized within the Council of Europe by virtue of the resolution of the Committee of Ministers of 27th March, 1980 on creation of the cooperation group combating drug abuse and drug trafficking.

However, at the Community (EU) level, it was only at the end of the 1980s that it became clear that the situation related to drugs and drug addiction cannot be analyzed only from the perspective of the individual member states. The first project involving the joint fight against drugs and drug abuse presented on the forum of the European Community was the so-called Seven-step Programme proposed by François Mitterrand. The ant-drug initiative suggested by the president of France in October 1989 was based on the following concepts. The first step - establishing common methods for the analysis of drug addiction in Europe leading to the creation of an European drug monitoring centre. The second step - harmonizing the drug policies of the member states. The third step - strengthening controls at the external borders and developing of methods of coordination between the activities of the competent authorities responsible for public security issues in the member states. The fourth step - assessing the implementation at the regional level of the United Nations Convention against illicit traffic in narcotic drugs and psychotropic substances of 1988, as well as accelerating its ratification by the member states. The fifth step - coordination of the member states activities regarding producer and transit countries as well as cooperation with these countries. The sixth step - defining a European Community policy on the laundering of drug money. The seventh step - designating in each EU country and the European Commission persons for contacts with respect to the problem issues ${ }^{1}$. The major point of this concept was creation of the drug monitoring centre studying not only the social and health aspects of the prob-

1 Source: http://www.emcdda.europa.eu/html.cfm/index1714EN.html, [date of access: 05.12.2018]. 
lem in Europe but also other related issues, including drug trafficking and criminal sanctions ${ }^{2}$.

In response to the French proposal, even in the same year, the European Council made a decision to create a European committee ad hoc on the drug policy ${ }^{3}$. In 1990, a significant effect of the Commission's activities was the adoption of the first European Plan to Combat Drugs which postulated a common approach to the drug problem not only in the social and health sphere, but also from the criminal and legal point of view. The document provided recommendations regarding, among others, reducing the demand for drugs, combat with trafficking and improving coordination of the activities at the level of the member states. Moreover, it should be noted that the Plan was the first step towards developing a programme of coherent actions against drugs and drug addictions both on the national and EU level. During the meeting in Dublin in June 1990, the European Council emphasized that any effective activities of all Member States related to drugs must be supported by the joint activities of the Community. During the meeting in Luxemburg in June 1991, the European Council, being largely influenced by the provisions of the United Nations Convention against Illicit Traffic in Narcotic Drugs and Psychotropic Substances of 20th December, $1988^{4}$, approved the project of creation of the European Monitoring Centre for Drugs and Drug Addiction.

The EMCDDA was established on the basis of the Council Regulation (EEC) No. 302/93 of 8th February, 1993 on the creation of the European Monitoring Centre for Drugs and Drug Addiction'. Presently, however,

2 M. Kosacka, Europejskie Centrum Monitoringu Narkotyków i Uzależnienia Narkotykowego [The European Drugs and Drug Addiction Monitoring Centre], In: Agencje Unii Europejskiej [Agencies of the European Union], ed. A. Dumała, Warsaw 2002, p. 146.

3 In French Comité européene pour la lutte anti-drogue - CELAD. On CELAD see more, e.g. J. Lodge, Internal security and judicial co-operation beyond Maastricht, "Terrorism and Political Violence" 1992, No. 4, pp. 1-29; M. Elvins, Anti-Drugs Policies of the European Union. Transnational Decision-Making and Politics of Expertise, London 2003, pp. 82-99.

4 The United Nations Convention on Combating Illicit OJ of 1995 No. 15, item 69.

5 The Council Regulation (EEC) No. 302/93 of 8th February, 1993 on the establishment of the European Monitoring Centre for Drugs and Drug Addiction, OJ L 36 of 12th December, 1993. The first amendment to Regulation No. 302/93 took place in 1994 and was a result of the need to harmonize the financial regulations applicable to the decentralized EU bodies (see the Regulation of the Council (EU) No. 3294/94 of 22nd 
the legal basis for the functioning of the European Monitoring Centre for Drugs and Drug Addiction is the Regulation (EC) No. 1920/2006 of the European Parliament and Council of 12th December, 2006 .

The Centre works currently with all $28 \mathrm{EU}$ member states, Norway by special agreement and candidate countries.

\section{THE SYSTEM POSITION OF THE EUROPEAN MONITORING CENTRE FOR DRUGS AND DRUG ADDICTION}

The legal basis for the creation of the Centre was Article 352 of the Treaty on the functioning of the European Union specifying an open

December, 1994 amending the Regulation (EEC) No. 302/93 on creation of the European Monitoring Centre for Drugs and Drug Addiction, OJ L 341 of 30th December, 1994). The second change was introduced by the Regulation of the Council (EC) No. 2220/2000 of 28th September, 2000 amending the Regulation (EEC) No. 302/93 on the creation of the European Monitoring Centre for Drugs and Drug Addiction (OJ L 253 of 7th October, 2000). As a result, the agency's competencies were expanded so as to, at the request of the Centre Committee, be able to make its drug and drug abuse know-how available to the candidate states meeting the requirements of the PHARE program and to help them create and strengthen the structural links with the REITOX network. On 18th June, 2003, the third amendment to the Regulation of 1993 was adopted [see the Regulation of the Council (EC) No. 1651/2003 of 18th June, 2003 amending the OJ L 245 of 29th September, 2003]. The changes introduced concerned two issues. Firstly, the general principles and restrictions regulating the right of access to the documents possessed by the Centre. Secondly, the regulation on the agency' budged was amended again. On 31st August, 2005, the Committee set forth a proposal for the re-drafting of the regulation on the way the EMCDDA operates and its internal structure. The introduction of the new changes resulted mainly from the necessity to increase the mandate of the agency in order to include in its tasks the study of new trends in using drugs involving a combination of the legal and illegal psychotropic substances. In addition, it was necessary to make it possible for the Centre to develop some tools and instruments helping the Member States and the Union monitor and assess their policy and strategies concerning drugs. It was also necessary to introduce changes in order to adjust the EMCDDA bodies functioning to the process of admitting new Member States to the Union. Moreover, it was suggested to create an executive committee to support the activities of the Management Board.

6 Regulation (EC) No. 1920/2006 of the European Parliament and Council of 12th December, 2006 on the European Monitoring Centre for Drugs and Drug Addiction, OJ L 376 of 27th December, 2006, further referred to as Regulation No. 1920/2006. 
clause allowing the Union to undertake actions outside the competencies explicitly granted in the Treaty should it prove necessary to attain one of the objectives of the European Union?

Achieving the set goals and the effective implementation of the tasks are possible due to the EMCDDA independence from both the European Union institutions as well as the authorities of the member states and citizens. It should be assumed that the tasks and goals set out for the Centre determine its political position and organizational structure. The legal solutions adopted in relation to the political position and the organizational structure of the Agency are supposed to result in the involvement of various entities interested in the EMCDDA's activities, independence from the external pressures and transparency of its functioning. Therefore, the independence of the Centre should be considered in three aspects: a) legal independence, b) financial independence, c) administrative independence.

A feature that distinguishes the Centre from other EU institutions or bodies is the fact that this agency possesses its own legal personality (different from the EU legal personality). The provision of Article No. 1920/2006 expressis verbis grants the Centre a legal personality. The agency, just like the European Union, has in each of the member states the legal capacity to the greatest extent possible granted to legal persons according to their internal legal order, particularly, the EMCDDA can acquire and dispose of movable and immovable property and be a party to legal proceedings ${ }^{8}$. In relation to its staff, mainly consisting of the leading experts in drugs and drug addiction, the Centre shall exercise the powers devolved to the appointing authority9. The Management Board can also adopt the appropriate implementing rules allowing the national experts from other member states to be employed in the EMCDDA on secondment ${ }^{10}$. The Center's employees, like in other EU agencies, are subject to

7 Treaty on the Functioning of the European Union, consolidated version, OJ C 326 of 26th October, 2012, further referred to as TFUE. Before The Treaty of Lisbon it was Article 308 Treaty establishing the European Economic Community.

8 Article 335 TFUE and Article 8 paragraph 1 sentence 2 and 3 of Regulation No. $1920 / 2006$.

9 Article 18 sentence 3 of Regulation No. 1920/2006.

10 Article 18 sentence 5 of Regulation No. 1920/2006. 
the provisions applicable to other employees and officials of the European Union ${ }^{11}$.

In relation to the contractual obligations, the Centre uses the regime relevant to a given agreement, however, providing that the Court of Justice is competent to adjudicate in compliance with the arbitration clause contained in a given agreement ${ }^{12}$. The non-contractual liability of the EMCDDA, however, involves the liability for any damage caused by the agency or its staff in the performance of their duties. In such a situation, the Centre is obliged to make good to any damage according to general principles common to the laws of the Member States. The Court of Justice has jurisdiction in disputes relating to the compensation of any such damage ${ }^{13}$. The Centre staff, according to the provisions of the Staff Regulations, may additionally have the personal liability ${ }^{14}$.

The financial independence of the Centre is proved by the fact that it has its own budget which is approved by the Management Board. The Centre's revenue includes: a) a Union subsidy from the general budget, b) payments for services rendered, c) any financial contributions from the organizations and bodies and third countries the Centre cooperates with ${ }^{15}$. As far as the Centre's revenue from the third countries is concerned, it should be noted that presently it includes financial means coming from two countries: Norway and Turkey. The Centre's expenditure includes: a) the Centre's staff expenditure (e.g. remuneration, business trip expenses, training expenses, retirement pensions, b) administrative and infrastructure expenses (e.g. expenses connected with the current administration, office maintenance costs), c) operating costs (e.g. research costs, publication and information costs, translation costs, data collection costs, d) expenditure in support of the REITOX focal points ${ }^{16}$.

The functioning of the Centre is also characterized by the administrative independence. The EMCDDA possesses its own bodies: a) Management Board (the decision-making body), b) Directorate (executive body),

11 Article 18 sentence 1 of Regulation No. 1920/2006.

12 Article 19 paragraph 1 of Regulation No.1920/2006.

13 Article 19 paragraph 2 of Regulation No.1920/2006.

14 Article 19 paragraph 3 of Regulation No.1920/2006

15 Article 14 paragraph 3 of Regulation No.1920/2006.

16 Article 14 paragraph 4 of Regulation No.1920/2006. 
c) Scientific Committee (assisting body) ${ }^{17}$. An effective implementation of tasks set out for the Centre depends on the well-organized structure. Due to this fact, the Centre's scientific activities are based on the work of the supporting groups which are in charge of: monitoring and analyzing drug situations, monitoring and assessing the drug-related activities, monitoring and assessing new synthetic drugs, monitoring and analyzing the policy and strategies in individual countries and in the European Union, as well as their impact on the situations caused by drugs. Additionally, these working groups are supported by the following units: coordination of the REITOX network, communication and information technology, dissemination of information and administration ${ }^{18}$.

\section{OBJECTIVES AND TASKS OF THE EUROPEAN MONITORING CENTRE FOR DRUGS AND DRUG ADDICTION}

The European Monitoring Centre for Drugs and Drug Addiction as a decentralized EU agency whose task is to provide the EU and the member states with objective, reliable and comparable information on drugs and drug addiction and its consequences in the European Union ${ }^{19}$.

The agency's activities are primarily aimed at providing a reliable and documented picture of drug and drug addiction-related phenomena in the area of Europe and in each of the member states of the European Union. The undertakings carried out by the Centre are supposed to provide the

17 More about the organizational structure of the Centre e.g. P. Wawrzyk, Wymiar organizacyjny agencji Unii Europejskiej. Struktury organizacyjne, procesy decyzyjne, finansowanie. Wnioski na przyszłość [Organization of the European Union. Organizational structures, decision-making processes, financing. Conclusions for the future], In: Agencje, komitety i inne jednostki organizacyjne w Unii Europejskiej [Agencies, committees and other organizational units in the European Union], Warsaw 2015, pp. 65-80; A. Doliwa-Klepacka, Z. Doliwa-Klepacki, Struktura organizacyjna (instytucjonalna) Unii Europejskiej [Organisational (institutional) structure of the European Union], Białystok 2009, s. $413-415$.

18 Source: http://www.emcdda.europa.eu/about/organisation, [date of access: 10.12. 2018].

19 K. Łucarz, A. Muszyńska, Ustawa o przeciwdziałaniu narkomanii. Komentarz [Act on drug abuse prevention. Comments], Warsaw 2008, Lex system. 
decision-makers with data, analyses and instruments necessary to prepare appropriate legislative solutions and drug strategies. In order to achieve the intended objectives, the agency is obliged to implement the clearly defined tasks.

The activities undertaken by the Centre include four key areas ${ }^{20}$. Firstly - collecting and analyzing the existing data. Secondly - improving the methods of data comparison. Thirdly - data dissemination and obligation to provide information. Fourthly - cooperation with the European and international bodies and organizations as well as the third countries. Within the first type of tasks, the Centre mainly collects, records and analyzes information obtained from the European Union, the member states, but also from the national non-governmental organizations and relevant international organizations. The Agency is also required to provide information on the best practices applied in the Member States and to facilitate the exchange of such practices among them. In addition, the Centre makes efforts to facilitate the exchange of information among the policymakers, scientists, specialists and persons operating in the drug-related areas in the governmental and non-governmental organizations, for instance, by creating and coordinating the European Information Network on Drugs and Drug Addictions.

In order to effectively implement the tasks related to the methods of data comparison, the Centre's activity in this field is supposed to ensure a better comparability, objectivity and reliability of data at the European level by defining indicators and common non-binding criteria, the compliance with which may be recommended by the Agency. Apart from that, the Centre prepares tools and instruments used to help the Union Member States to monitor and assess their national policies, and the Commission - to monitor and assess the EU policies. The Agency also facilitates and structures the qualitative and quantitative exchange of information.

Within the third type of tasks, the agency primarily makes the prepared information available to any interested entities. The Centre also ensures broad dissemination of work implemented in each Member State and the Union itself, and of the reliable, available to the public data possessed by the Agency. In order to achieve this goal, the Centre publishes annual reports

20 Article 2 of Regulation No.1920/2006. 
on drug problems. It is also obligated to inform all bodies of the member states on any new phenomena or change in trends, should they occur.

In order to ensure an effective cooperation with the interested entities, the agency contributes to the improvement of coordination among the national and EU activities undertaken with respect to drugs and drug addiction. It actively cooperates with Europol and also supports the inclusion of data on drugs and drug addiction, collected in the member states or coming from the EU, to the international drug monitoring and control programmes, particularly those, established by the UNO and its specialized agencies.

The information that the Centre collects, analyzes and then makes available and disseminates, relates particularly to: the demand for drugs and its restrictions, policies and strategies of the individual member states and the EU countries in the field of drugs and drug addiction, international cooperation and supply geopolitics, control of drug and psychotropic substances, precursors, the effects of drug addiction and drug-related phenomena for the countries of producers, recipients and the transit countries.

Pursuant to the provisions of Article 3 of Regulation No. 1920/2016, the agency implements its goal and tasks in the specific priority areas. Firstly - monitoring the state of the drug-related problems, especially using epidemiological and other indicators and monitoring the emerging trends, particularly, those involving the use of various types of drugs at the same time. The monitoring of the drug and drug addiction phenomena is based on collecting and analyzing the data in terms of five key indicators: drug use among the general population, treatment demand, drug-related infectious diseases, drug-related deaths and mortality among drug addicts, problem related use of drugs. Secondly - monitoring the solutions applied with respect to drug-related problems and also providing information on the best practices in the member states and facilitating the exchange of such practices among them. Thirdly - assessment of the risk related to the new psychotropic substances and maintaining a system of fast exchange of information on their use, as well as information on the new ways of using the existing psychoactive substances. Fourthly - development of tools and instruments to facilitate the monitoring and assessment of their national policies for the member states, whereas the monitoring and assessment of the EU policies for the European Commission. 
The information collected and analyzed by the Agency includes a wide range of areas. The Centre is particularly interested in the data on such areas as: problem-related use of drugs, demand for drug addiction treatment, drug-related death, using drugs by children and adolescents, drug addiction in prisons, drug confiscation or relationship between the price and purity of the substances offered.

The present range of tasks scheduled for the Centre is also determined by the assumptions of the EU anti-drug strategy for the years 2013-202021 and the EU action plan on drugs adopted on these grounds and concerning the narcotic drugs, for the years 2017-202022. The EU anti-drug strategy for the years 2013-2020 makes it its priority to develop effective policies in the field of drug supply reduction by strengthening the assessment of policies and an analysis to better understand the drug markets and drug-related crimes, as well as the improvement of the effectiveness of the response of the enforcement agencies to drug issues. On the other hand, one of the activities included in the EU action plan for the years 2017-2020 with respect to drugs is "to contribute to a better understanding of all aspects of the drugs phenomenon and of the impact of intervention in order to provide a sound and comprehensive evidence base for policies and actions". In the context of the documents and initiatives cited, it ought to be pointed out that the Centre was obligated, among others, to promote the evidence-based assessment of policies and interventions at national, EU and international levels, to better disseminate the results of monitoring, studies and evaluation at the EU and national levels, to maintain networks of contacts, to cooperate and develop, internally and horizontally within the UE infrastructure, knowledge and potential associated with information, research, monitoring and evaluation with respect to narcotic drugs, particularly, illicit drugs.

The EMCDDA also implements various projects addressed to the EU candidate countries or to the potential candidate countries. In July 2017, the agency commenced work on the action referred to as IPA 6 (Instrument of Pre-accession Assistance, IPA). The beneficiaries of the project are

21 The EU anti-drug strategy for the years 2013-2020, OJ C 402 of 29th December, 2012.

22 The EU action plan on drugs for the years 2017-2020, OJ C 215 of 5th July, 2017. 
Albania, Bosnia and Herzegovina, Macedonia, Kosovo, Montenegro and Serbia. The objective of the undertaking is to support the IPA 6 beneficiaries in their preparations for participation in the Centre's activities and the REITOX network. This goal will be achieved by: a) strengthening the cooperation and communication among EMCDDA and each beneficiary at the institutional level, b) developing scientific cooperation with respect to data collection, analysis and interpretation, c) strengthening the national early warning systems ${ }^{23}$.

The EMCDDA is not a research centre in any formal sense $e^{24}$. The agency is the main information centre on the problem of drugs at the EU level ${ }^{25}$. The nature of this agency was explicitly defined in the provisions of Regulation 1920/2006. The Centre cannot take any measures that go beyond the sphere of information and its processing. The major outcome of the agency's work is an annual review of the drug situation in Europe. It not only presents the status of the drug problem in Europe and individual countries (presently about 40), but it also reviews the methods of reacting to the drug problem, which helps individual countries to follow trends and develop their own strategies. What is more, the agency has developed a programme of publications addressed to a wide range of recipients. Each year, within the allocated tasks, the Centre publishes an annual report on the state of the problem of drugs and drug addiction in the European Union as well as a general report of its activities. Additionally, the EMCDDA published two periodicals: the "Drugnet Europe" newsletter and a series of short compilations "Drugs in focus" The Agency also publishes scientific monographs, analyses, textbooks, reports, brochures and leaflets ${ }^{26}$.

23 Source: http://www.emcdda.europa.eu/about/partners/cc, [date of access: 9.12. 2018].

24 P. Griffiths, J. Mounteney, D. Lopez, F. Zobel, W. Götz, Monitoring the European drug situation:the ongoing challenge for the European Monitoring Centre for Drugs and Drug Addiction (EMCDDA), “Addiction” 2012, No. 107, p. 257.

25 About classification of EU agencies and their activitities see more e.g. M. Zieliński, Klasyfikacje agencji zdecentralizowanych Unii Europejskiej [Classifications of the decentralised agencies in the European Union], "Studia Prawnicze KUL" 2017, No. 1(69), pp. 179-200; A. Kreher, Agencies in the European Community - a step towards administrative integration in Europe, "Journal of European Public Policy" 1997, No. 2, pp. 225-245.

26 Source: http://www.emcdda.europa.eu/publications, [date of access: 9.12.2018]. 


\section{COOPERATION OF THE EUROPEAN MONITORING CENTRE FOR DRUGS AND DRUG ADDICTION WITH OTHER ENTITIES}

The multidisciplinary nature of the drug problem makes it the object of interest of numerous working groups of the EU institutions and bodies, as well as the international organizations.

Due to this fact, in order to effectively implement its tasks, the Centre is obliged to cooperate with EU institutions, such as: the European Parliament, the Commission and Council of the European Union. The cooperation with the Parliament is carried out mostly by contacts with its committees, in particular, the Committee for on Civil Liberties, Justice and Home Affairs $^{27}$. The agency is obliged to present this parliamentary committee its annual report on the state of the drug problem in Europe the day before it is published in the international press (usually in the first week of November).

Apart from that, the EMCDDA cooperates with the European Commission $^{28}$. The cooperative activities of these entities results from the fact that the Commission undertakes individual initiative with respect to public health protection, with particular emphasis on the issue of drugs and drug addiction. The data collected and analyzed by the agency also have an impact on the directions of the undertakings implemented by the Commission on the grounds of such documents as, for example, the anti-drug strategy or European Union action plans related to drugs. What is more, within the delegated tasks, the Centre also cooperates with the standing working committee of the Commission (the Standing Committee on Precursors) on issues related to the control and monitoring of chemical explosive precursors.

The activities undertaken by the Centre are also associated with the socalled Horizontal Working Party on Drugs functioning within the Council of the European Union, which, just like the agency, deals with the exchange of information and assessment of drug policies and problems in the $\mathrm{EU}$, identification of key issues concerning more than one member state

27 Source: http://www.emcdda.europa.eu/about/partners/ep, [date of access: 12.12. 2018].

${ }_{28}$ Source: http://www.emcdda.europa.eu/about/partners/ec, [date of access: 12.12. 2018]. 
and with improvement of the coordination of activities undertaken by the member states inside and outside the European Union. What is more, this group is responsible for preparation of drug strategy projects and action plans on drugs. As the member of this working group, EMCDDA contributes regularly to its work by providing expertise, information as well as and drug-related analyses ${ }^{29}$.

In order to effectively carry out its tasks, the Centre also cooperates with other EU agencies, including in particular: the European Police Office, the European Centre for Disease Prevention and Control and the European Medicines Agency. The most important partner of the Centre is the European Police Office. Presently, the cooperation of these two agencies is focused on three aspects. Firstly - undertakings directly related to the implementation of the tasks defined in the EU Action Plan on narcotic drugs for the years 2017-2020, leading to intensified monitoring of the illicit drug supply in Europe. Secondly - cooperation in the field of information exchange, risk assessment and control of new psychoactive substances, Thirdly - exchange of strategic information and work methodology.

The Centre also cooperates with the European Centre for Disease Prevention and Control through the exchange of knowledge and good practices. Both agencies work together in order to disseminate information, monitor and prevent the spread of infectious drug-related diseases in Europe. The European Centre for Disease Prevention and Control explores the trends in such diseases in the whole society, whereas the European Monitoring Centre for Drugs and Drug Addiction, as the specialist source of information on drugs, focuses on a specific risk group of persons taking drugs intravenously. The cooperation of the Centre with ECGC resulted, for example, in the publication of common European guidelines on the prevention of HIV and other infections among persons taking drugs intravenously.

As part of the early warning system on new drugs and the risk assessment associated with new substances, the Centre cooperates with the European Medicines Agency. In order to ensure a fast and reliable information exchange, the agencies use electronic tools in form of the existing databases: EudraVigilance (from the EMA website) and the European

29 Source: http://www.emcdda.europa.eu/about/partners/council, [date of access: 12.12.2018]. 
Database on New Drugs (from the EMCDDA website). The Centre's activities, although to a lesser extent, are also associated with the tasks implemented by Eurojust and European Police College.

Due to the cross-border nature of the drug problem and the range of its impact, it is necessary for the EMCDDA to cooperate with the international organizations in order to ensure a proper implementation of the goals allocated for the Centre. The most important international partners of the Centre include: a) The United Nations Office on Drugs and Crime, b) the World Health Organization, c) The Pompidou Group of the Council of Europe.

The framework of the EMCDDA's cooperation with the United $\mathrm{Na}$ tions Office on Drugs and Crime is established by the Memorandum signed in Vienna on 13th March, $1998^{30}$. The cooperation of the organizations is supposed to result in: a) improvement of data collection and analysis, b) development and promotion of methods for comparing information, c) improvement of dissemination of the information possessed. Moreover, the joint activities are also carried out in form of practical programmes. The joint cooperation programme was adopted in 2007 and it serves to strengthen the cooperation in the field of: epidemiology, reduction of demand, reduction of drug supplies, legal information systems, new trends in drug use.

The cooperation between the Centre and the World Health Organization began in 1995 when the EMCDDA actually commenced its activity $^{31}$. It involves the exchange of information, data and methodological instruments. In the area of mutual interests of both organizations, there are issues related to, for example, drugs in prisons, drug-related diseases and social consequences of drug abuse.

Since the beginning of its establishment, the EMCDDA also closely cooperates with the Pompidou Group within the Council of Europe ${ }^{32}$.

30 Source: http://www.emcdda.europa.eu/about/partners/unodc, [date of access: 12.12.2018].

31 Source: http://www.emcdda.europa.eu/about/partners/who, [date of access: 12.12. 2018].

32 On Pompidou Group see more e.g. Stauffacher M., Kokkevi A., The Pompidou Group Treatment Demand Protocol: The First Pan-European Standard in the Field, "European Addiction Research” 1999, No. 5, pp.191-196. 
The effective cooperation of these two organizations is based on the principle of mutual recognition, complementarity, accuracy of the collected resources as well as avoiding duplication of the undertaken activities ${ }^{33}$. In order to achieve the intended effects, the Centre participates in the work of the Group's thematic platforms, such as: prevention, medical treatment, research. On behalf of the Pompidou Group, its representative takes part in the meetings of the EMCDDA Management Board as an observer.

Moreover, the EMCDDA is involved in the work within the Joint United Nations Programme on HIV/AIDS. It also cooperates with, among others, such as: the International Criminal Police Organization, the InterAmerican Drug Abuse Control Commission, the European School Survey Project on Alcohol and Other Drugs, the World Customs Organization.

The implementation of the tasks allocated to the Centre would not be also possible without a cooperation with the national centres of the member states. The exchange of useful information also takes place via the computer network - the European Information Network on Drugs and Drug Addiction (Reitox). The function of Reitox is to improve the exchange of data among the national and international institutions involved in counteracting drug addictions. Its task is also to support and initiate appropriate anti-drug programmes at the national level ${ }^{34}$.

\section{CONCLUSIONS}

The problem of drugs can be analyzed from different perspectives, ranging from the political and health to research perspective. In order to undertake effective activities in the combat with drugs, it is necessary to possess reliable scientific information that support the drug-related discussions. At the EU level, the activity of the European Monitoring Centre for Drugs and Drug Addiction remains invaluable in this respect.

33 Source: http://www.emcdda.europa.eu/about/partners/pompidou, [date of access: 12.12.2018].

34 T. Srogosz, Ustawa o przeciwdziałaniu narkomanii. Komentarz [Act on drug abuse prevention. Comments], Warsaw 2008, Legalis system. 
The EMCDDA covers a wide range of drug-related topics, across epidemiology, interventions, laws and policies. The Centre has a broad contact network, with many hundreds of national experts and scientists and interacts with many institutions and organizations to complement and support the scientific discourse on drug use in Europe.

The agency provides a formal legal channel at European level for the identification, risk, assessment and possible control of new psychoactive substances. The activities of the Centre help experts in this field to identify best practices and new areas of research. Although the EMCDDA does not propose any specific solutions, it still has a significant impact on the decision-making process by providing analyses, standards and tools. The agency also helps to define new drugs and respond to them.

Analysis of drug-related trends and developments prepared by the EMCDDA provide a useful tool to determine European and national strategies and interventions on the most recent information available. Data collected by the Centre are used as baseline and follow-up data for policy and service evaluations, to give context and help define priorities for strategic planning, to enable comparisons to be made between national situations and datasets and to highlight emerging threats and issues.

\section{REFERENCES}

Doliwa-Klepacka A., Doliwa-Klepacki Z. 2009, Struktura organizacyjna (instytucjonalna) Unii Europejskiej [Organisational (institutional) structure of the European Union], Białystok.

Elvins M. 2003, Anti-Drugs Policies of the European Union. Transnational Decision-Making and Politics of Expertise, London.

Griffiths P., Mounteney J., Lopez D., Zobel F., Götz W. 2012, Monitoring the European drug situation: the ongoing challenge for the European Monitoring Centre for Drugs and Drug Addiction (EMCDDA), Addiction, No 107.

Kosacka M. 2002, Europejskie Centrum Monitoringu Narkotyków i Uzależnienia Narkotykowego [The European Drugs and Drug Addiction Monitoring Centre], In: Agencje Unii Europejskiej [Agencies of the European Union], ed. A. Dumała, Warsaw.

Kreher A. 1997, Agencies in the European Community - a step towards administrative integration in Europe, Journal of European Public Policy, No. 2. 
Lodge J. 1992, Internal security and judicial co-operation beyond Maastricht, Terrorism and Political Violence, No. 4.

Łucarz K., Muszyńska A. 2008, Ustawa o przeciwdziałaniu narkomanii. Komentarz [Act on drug abuse prevention. Comments], Warsaw.

Srogosz T. 2008, Ustawa o przeciwdziałaniu narkomanii. Komentarz [Act on drug abuse prevention. Comments], Warsaw.

Stauffacher M., Kokkevi A. 1999, The Pompidou Group Treatment Demand Protocol: The First Pan-European Standard in the Field, European Addiction Research, No. 5.

Wawrzyk P. 2015, Wymiar organizacyjny agencji Unii Europejskiej. Struktury organizacyjne, procesy decyzyjne, finansowanie. Wnioski na przyszłość [Organization of the European Union. Organizational structures, decision-making processes, financing. Conclusions for the future], in: Agencje, komitety $\mathrm{i}$ inne jednostki organizacyjne w Unii Europejskiej [Agencies, committees and other organizational units in the European Union], (ed.) M. Witkowska, K. A. Wojtaszczyk, Warsaw.

Zieliński M. 2017, Klasyfikacje agencji zdecentralizowanych Unii Europejskiej [Classifications of the decentralised agencies in the European Union], Studia Prawnicze KUL, No. 1(69). 
